\title{
The Effect of Frequent Dictation on the Listening Comprehension Ability of Elementary EFL Learners
}

\section{G. Reza Kiany and Ebrahim Shiramiry}

This study investigated the effects of frequent dictation on the listening comprehension (LC) ability of elementary EFL learners. Two homogeneous groups of elementary EFL learners at the Kish Language Institute in Tehran, Iran were chosen. Each group consisted of 30 male elementary EFL students, 20 to 35 years of age. All the participants had had the same amount of exposure to listening materials before the experiment, and all had studied English for three terms (each term consisting of 20 sessions of 100 minutes each) at the Kish Language Institute. One of the groups was chosen as the experimental group, and the other as the control group. For one term, consisting of 20 sessions, the students in the control group were given the listening exercises in their textbook, Headway Elementary (Soars $\mathcal{E}$ Soars, 1993). The experimental group, in addition to the listening exercises in the textbook, were given dictation 11 times during the term. At the end of the term the LC ability of both groups was posttested by a battery of 40-item NCTE Elementary Listening Tests (National Council of Teachers of English, 1972), which was also used as the listening pretest. The results showed that dictation had a significant effect on the listening comprehension ability of the participants in the experimental group. The mean gain scores of the experimental group were significantly higher than those of the control group.

Cette étude traite de l'effet des dictées administrées de façon régulière sur la compréhension auditive d'étudiants ALE en Iran. Deux groupes homogènes d'étudiants intermédiaires en ALE inscrits au Kish Language Institute à Téhéran, en Iran, ont été choisis pour participer à la recherche. Chaque groupe consistait de 30 hommes de niveau intermédiaire étudiant l'anglais comme langue étrangère. L'âge des participants était de 20 à 35 ans et tous avaient déjà été exposés de la même façon à du matériel didactique pour développer l'écoute et avaient étudié l'anglais pendant trois semestres (chaque semestre consistant de 20 sessions de 100 minutes chacune) au Kish Language Institute. Un des groupes a été sélectionné pour être le groupe expérimentale et l'autre, le groupe témoin. Pendant un semestre - 20 sessions - les étudiants du groupe témoin ont suivi les exercices d'écoute dans leur texte, Headway Elementary (Soars $\mathcal{E}$ Soars, 1993). En plus d'accomplir ces mêmes exercices, le groupe expérimental a fait 11 dictées au cours du semestre. À la fin du semestre, les deux groupes ont passé une batterie de tests pour évaluer leur compétence à l'écoute en langue étrangère 
(National Council of Teachers of English Elementary Listening Tests, 1972). Les résultats indiquent que les dictées ont eu un effet significatif sur la compréhension auditive des participants dans le groupe expérimental. L'amélioration moyenne des étudiants du groupe expérimental était beaucoup plus importante que celle des étudiants du groupe témoin.

\section{Introduction}

Celce-Murcia (1991) states, "the importance of listening comprehension in language learning and language teaching has moved from a status of incidental and peripheral importance to a status of significance and central importance" (p. 105). Listening comprehension (LC) is gradually receiving the emphasis it has always deserved. Second-language educators now acknowledge it as a crucial skill in second-language learning and encourage language teachers to devote more class time to listening activities. The importance of listening cannot be overestimated. Chastain, (1988) asserts,

The ability to comprehend the spoken second language plays an essential role in second-language learning and use. It is one of only two sources of new linguistic data and general information. It is the more important of the two skills involved in all types of oral exchange. It is a necessary skill for classroom oral communication activities. It is an indispensable skill for oral communication out of class. It is the skill that tends most to impede oral communication between native and non-native speakers. And it is the skill most needed out of class by language students attempting to improve their knowledge and use of the second language. (p. 209)

Brown (1993) affirms, "there has been a revolution in the teaching of English" (p. 1). Before the 1970s it was still the case that spoken language was given secondary importance. Today the importance of teaching the spoken language is universally acknowledged. This revolution has ensured that the problems of understanding the spoken form of the foreign language have received increasing attention both in research and pedagogy. We now have a much better understanding of the processes of comprehension. Many courses now offered aim to teach listening comprehension, and many books and conferences claim to teach teachers how to improve their students' performance in listening comprehension. Furthermore, many teaching techniques in this regard have been introduced. For example, Ur (1991) has presented more than 30 types of exercises for teaching listening. Similarly, Rost (1991) has suggested more than 30 activities with many variations.

One of the techniques for improving listening comprehension that is recommended in many books about teaching EFL in general and teaching listening comprehension in particular is dictation (Celce-Murcia, 1996; Gil- 
bert, 1996; Davis, 1995; Rost, 1991; Ur, 1991; Byrne, 1978; Rivers \& Temperley, 1978; Morley, 1977; Paulston, 1976; Finocchiaro \& Bonomo, 1973).

According to the Longman Dictionary of Language Teaching and Applied Linguistics (Richards, Platt, \& Platt, 1992), "Dictation is a technique used in both language teaching and language testing in which a passage is read aloud to students, with pauses during which they must try to write down what they heard as accurately as possible" (p. 108). Davis (1995) lists 10 reasons for using dictation in EFL classes, including giving a good listening practice to the whole class in a short time and making students listen attentively. Morley's (1977) book Listening Dictation is about using dictation to develop basic skills in discriminative listening and in extracting meaning from spoken English sentences. Ur (1991) recommends using dictation exercises as an activity for listening both for perception and comprehension.

In this study, dictation is used only as a teaching technique for improving the listening comprehension ability of elementary EFL learners. Conducting such a study seemed necessary because using dictation as a listening exercise has been recommended in many books about language teaching, but no research has been done to investigate the effect of dictation on the listening comprehension ability of Iranian EFL learners.

\section{Research Question}

This study examined the following research question: Is there a significant difference between the listening comprehension ability of elementary EFL learners who are given frequent dictation exercises and the listening comprehension ability of those who are not?

\section{The Study}

This study was conducted in April 2000 at the Kish Language Institute in Tehran. Sixty Iranian elementary EFL learners were chosen. They were all male, and their ages ranged from 20 to 35 . These 60 participants were in four classes. Before the experiment all had been studying English in the Institute for three 20-session terms, approximately 100 hours each (at Kish each session is 100 minutes and students attend the class five sessions/days a week). Thus the students had been exposed to the same amount of English and listening practice. Two of the classes, consisting of 30 students, were assigned randomly to the experimental group, and the other two classes, consisting of another 30 students, were assigned as the control group. To assure the homogeneity of the two groups in terms of their general proficiency and listening ability in English, students were given as pretests the Nelson Test 100A (Fowler \& Coe, 1976) and the NCTE Elementary Listening Test (NCTE, 1972). T-test analysis indicated no significant difference prior to treatment in general English proficiency $(t(58)=-.38, N S)$ and no significant difference in listening comprehension ability $(t(58)=.49, N S)$. 
The instructor of the four classes participating in the study was the co-researcher of this study, Ebrahim Shiramiry.

In the treatment, the two classes in the experimental group were given not only the listening exercises of their book, but also 11 dictation exercises. The two classes in the control group were given only the listening exercises in their book. The passages and conversations used for dictation were short, consisting of about 100 words each, and each dictation would take around 10-15 minutes. While taking dictation, the class was quiet and the quality of the tape and the cassette player was good.

The materials for giving dictation were the native-recorded passages and conversations in the course textbook. The procedure to carry out the treatment, giving dictation, was as follows. First, students were made aware of the topic of the passage or conversation to activate their background knowledge; they then listened to the whole passage or conversation without any pauses. Second, the tape was replayed and stopped after each meaningful chunk, and students wrote down what they heard. In the third stage they listened again to the whole passage or conversation to check what they had written. After the dictation they checked their writing against the tapescript in their textbook. Sometimes after checking their dictation, participants listened to the tape again while looking at their dictation and paying special attention to their mistakes.

At the end of the term the LC ability of the participants was posttested with the same NCTE Elementary Listening Test used to pretest the listening comprehension ability of the two groups before the treatment. The data were analyzed using the SPSS program. Table 1 shows the mean scores and standard deviations of the pretest, posttest, and gain scores of each group.

T-test analysis of pretest mean scores of the two groups (Experimental group 54.00 vs. control group 56.00) indicated no significant difference $(t(58)=.49, \mathrm{NS})$. However, $t$-test analysis of the mean gain scores of the experimental (dictation) group of 13.91 was significantly higher than the mean gain score of the control group of $6.00(t(58)=20.59, p<.001)$.

Thus there is a significant difference between the gain scores of the experimental and control groups. This indicates that the experimental group

Table 1

Comparison of LC ability of experimental and control group

\begin{tabular}{lrrrrrrr}
\hline & \multicolumn{2}{c}{ Pretest } & \multicolumn{2}{c}{ Posttest } & \multicolumn{2}{c}{ Gain Scores } \\
& Mean & SD & Mean & SD & Mean & SD \\
\hline Experimental Group & 54.00 & 10.22 & & 68.58 & 10.39 & 13.91 & 1.42 \\
Control Group & 56.00 & 10.79 & 62.00 & 10.20 & 6.00 & 1.55 \\
\hline
\end{tabular}


that took dictation outperformed the control group in their performance on the listening comprehension test.

\section{Conclusions}

The aim of this study was to investigate the effect of frequent dictation on the listening comprehension ability of elementary EFL learners. Results indicate that dictation did have a significant effect on the listening comprehension ability of the experimental group. Thus the answer to the research question is Yes, there is a significant difference between the listening comprehension ability of those elementary EFL learners who are given frequent dictation and the listening comprehension ability of those who are not.

Probable reasons for the significant effect of dictation on the listening comprehension ability of the experimental group, may be as follows.

- The participants in the experimental group were forced to listen more attentively to decode the foreign speech.

- During each dictation participants had to keep one chunk of meaningful speech in their mind until they could write it on paper. This may have helped strengthen their memory.

- Dictation with recording of native speakers of English makes learners aware of difficulties of understanding English spoken by native speakers in comparison with the English spoken by Iranian EFL teachers. Native speakers' English is quite different from Iranian EFL teachers' English in terms of pronunciation, including pronunciation of some sounds, rhythm, sentence stress, weak forms, intonation, and linkage. This coincides with Kenworthy's (1990) recommendation to use dictation of native recorded speech to make learners aware of these aspects of pronunciation.

- When EFL learners are given dictation, they notice their weaknesses in perceiving and understanding English spoken by native speakers and try harder to improve their LC ability.

\section{Limitations}

The participants in this study were all male elementary Iranian EFL learners between 20 and 35 years of age studying English at Kish Language Institute in Tehran. In each group (the experimental and the control group) there were only 30 students. The students in both groups were taught by one instructor, the co-researcher of this study.

\section{Pedagogical Implications}

Because this study found that dictation can have a positive effect on the listening comprehension ability of elementary EFL learners, EFL teachers can use this technique in their classes with more confidence. 
In some countries such as Iran where students do not have access to native English speakers, EFL teachers can make use of this technique to familiarize their students with the English spoken by native speakers. If EFL students are exposed only to English spoken by Iranian EFL teachers, even after learning considerable grammar and vocabulary they cannot understand native English speakers easily. Dictation makes EFL learners aware of many aspects of the pronunciation of English spoken by native speakers. It may also affect their listening comprehension ability and their pronunciation. Using dictation to make students aware of different aspects of pronunciation and the sound system of English has been recommended both by Kenworthy (1990) and Celce-Murcia (1996).

Dictation can easily be used in various kinds of EFL classes. Dictation can be used not only as a listening exercise, but also as a listening test (Farhady, Jafarpoor, \& Birjandy, 1994; Celce-Murcia, 1996). It is recommended as a general English proficiency test (Oller, 1979). It can be used in error analysis studies (Hemmati, 1990). Some ELT experts, such as Bowen, Madson, and Hilferty (1985), have recommended it for teaching writing, and some have recommended it for teaching grammar (Morely, 1977; Kidd, 1992).

\section{Suggestions for Further Research}

Drawing on the theoretical concepts and practical procedures followed in this study, some related studies are recommended.

- The participants in this study were all male elementary EFL learners between 20 and 35 years of age. The study could be replicated with participants of higher levels of language proficiency or with participants of different ages and sex.

- This study investigated the effect of dictation of complete passages on the listening comprehension ability of EFL learners. Other studies could investigate the effect of gapped dictation or dicto-composition (Kidd, 1995) on listening comprehension ability of EFL learners.

- For example, dictation has been recommended in teaching other areas of language, such as grammar (Morley, 1977; Kidd, 1992), writing (Bowen et al., 1985), and pronunciation (Celce-Murcia, 1996;

Kenworthy, 1990). Research could investigate the effect of dictation on various areas of language.

\section{The Authors}

Gholam Reza Kiany (PhD, University of Essex, UK) is an assistant professor in the English Department of Tarbiat Modarres University, Tehran, Iran. His research interests are language testing and psycholinguistics.

Ebrahim Shiramiry (MA in ELT, Tarbiat Modarres University, Tehran) is a lecturer in the English Department of Sanandaj Azad Univerity, Sanandaj, Iran. His research interest is teaching methodology, and he has translated six books and several articles from English into Farsi. 


\section{References}

Bowen, J.D., Madson, H., \& Hilferty, A. (1985). TESOL: Techniques and procedures. Rowley, MA: Newbury House.

Brown, G. (1993). Listening to spoken English (2nd ed.). London: Longman.

Byrne, D. (1978). Teaching oral English. London: Longman.

Celce-Murcia, M. (1991). Teaching English (2nd ed.). New York: Newbury House.

Celce-Murcia, M. (1996). Teaching pronunciation. Cambridge, UK: Cambridge University Press.

Chastain, K. (1988). Developing second-language skills (3rd ed.). San Diego, CA: Harcourt College.

Davis, P. (1995). Dictation: New methods, new possibilities. Cambridge, UK: Cambridge University Press.

Farhady, H., Jafarpoor, A., \& Birjandy, P. (1994). Testing language skills: From theory to practice. Tehran: Samt.

Finocchiaro, M., \& Bonomo, M. (1973). The foreign language learner. New York: Regents.

Fowler, W.S., \& Coe, N. (1976). Nelson English language tests. London: Butler.

Gilbert, J.B. (1996). Clear speech (2nd ed.). Cambridge, UK: Cambridge University Press.

Hammati, F. (1990). On the validity of dictation as a pragmatic language test. Unpublished master's thesis, Tarbiat Modares University, Tehran, Iran.

Kenworthy, J. (1990). Teaching English pronunciation. London: Longman.

Kidd, R. (1992). Teaching ESL grammar through dictation. TESL Canada Journal, 10(1), 49-61.

Morley, J. (1977). Listening dictation. Detroit, MI: University of Michigan.

National Council of Teachers of English (NCTE). (1972). Elementary listening test. In English for today: Instructor's manual tests. New York: McGraw-Hill.

Oller, J.W., Jr. (1979). Language tests at school. London: Longman.

Paulston, C. (1976). Teaching English as a second language. Cambridge, UK: Winthrop.

Richards, J.C., Platt, J., \& Platt, H. (1992). Longman Dictionary of Language Teaching and Applied Linguistics (2nd ed.). London: Longman.

Rivers, W.M., \& Temperley, M.S. (1978). A practical guide to teaching of English. Oxford, UK: Oxford University press.

Rost, M. (1991). Listening in action. New York: Prentice-Hall.

Soars, L., \& Soars, J. (1993). Headway elementary. Oxford, UK: Oxford University Press.

Ur, P. (1991). Teaching listening comprehension. Cambridge, UK: Cambridge University Press. 